\title{
OPTIMALISASI DESAIN RESTROOM PADA BANGUNAN PUBLIK DI SURAKARTA
}

\author{
Agung Purnomo ${ }^{1)}$, Indarto ${ }^{2)}$ \\ ${ }^{1}$ Fakultas Seni Rupa dan Desain, Institut Seni Indonesia Surakarta \\ email: agpnomo@gmail.com \\ 2 Fakultas Seni Rupa dan Desain, Institut Seni Indonesia Surakarta \\ email: interior.hanindart@gmail.com
}

\begin{abstract}
Restroom is as a supporting facility in a public building functioning to be a room for such activities as washing hand, washing face, urinating, and defecating. This room is equipped with a variety of toilet sets including wastafel (was basin), and some forms of closet, bidet and urinoir and other room facilities such as tissue paper and rubbish basket. Surakarta as a cultural, business, and trading business have many public buildings. Attention should be paid to how those buildings can have supporting facilities such as restroom with good sanitation, comfortable, and cultured as the form of good public service to children, adult, and disabled. This applied research aims to answer the problem related to the function of sanitation and restroom form existing in Surakarta and to give design-related solution based on field and literature data. The research procedure included identification, design experiment, and design trial. To explore data of artifact, literature, and informant, observation, literature study, interview, and documentation techniques were used. Design experiment was conducted using design approach and confirmed with evocative, educative, psychological, and social-cultural approaches. Out put this research in the form of an optimal restroom design on local content aspects by including Surakarta batik motifs including 'kawung', 'truntum', and 'sidomukti' to be applied to the walls of the room. Restroom design also incorporates 'lingga'and 'yoni' shape transformation into wastafel design.
\end{abstract}

Keywords: optimization, restroom design, public building, Surakarta

\section{PENDAHULUAN}

\section{A. Latar Belakang}

Surakarta sebagai kota budaya memiliki sejarah panjang berkembangnya kerajaan besar di tanah Jawa, meskipun masanya telah berlalu oleh karena perubahan jaman auranya masih terasa kuat hingga di era melineal. Peninggalan adiluhung masa lalu baik berupa artefak dan tradisi masih dijaga dan dijalankan sebagai bentuk pelestarian sekaligus pengembangan. Surakarta pada saat ini giat melakukan pembangunan menuju kota budaya, bisnis dan perdagangan yang maju baik dari sisi infrastruktur dan sumber daya manusia tanpa mengesampingkan eksisting potensi kearifan lokal yang telah dimiliki.

Bangunan umum yang berorientasi budaya, bisnis dan perdagangan terus tumbuh baik di pusat maupun di kawasan perluasan kota Surakarta. Keberadaan bangunan-bangunan seperti gedung perkantoran, mall, hotel, pusat budaya dan pariwisata, stasiun maupun terminal moda transportasi, dan lain sebagainya merupakan sarana penggerak ekonomi daerah yang sebaiknya memiliki visi budaya dan fungsi yang universal. Sudah selayaknya bangunan-bangunan tersebut harus didukung dengan fasilitas utama dan penunjang yang memadahi tidak hanya dari segi kegunaannya tetapi juga karakter lokalitas budaya sehingga fungsinya bisa lebih optimal. Fasilitas penunjang yang ada di dalam sebuah gedung sebagai bangunan umum diantaranya area parkir, lobby, ruang rapat, restroom dan lain-lain.

Fasilitas penunjang berupa restroom pada bangunan umum di Surakarta menarik untuk diteliti berkaitan dengan fungsi dan bentukn- 
ya karena di lapangan masih banyak ditemukan permasalahan seperti sanitasi yang tidak baik sehingga mengakibatkan bau tidak sedap dan lantai tidak mudah mengering. Di samping itu interior restroom belum memberikan fungsi yang universal untuk seluruh masyarakat terutama pada segmentasi usia dan bagi mereka yang berkebutuhan kusus (disabilitas). Dengan demikian hal ini sangat penting untuk menjadi perhatian sebagai bentuk fasilitas pelayanan publik yang baik dan memeadahi. Data-data yang didapatkan di lapangan nantinya menjadi dasar di dalam pengembangan desain restroom sesuai kebutuhan, dengan demikian disain yang dihasilkan dapat diterapkan dengan sebaik-baiknya.

Restroom seperti yang dikutip dari kamus Cambridge Academic Content Dictionary memiliki difinisi berupa sebuah ruangan di gedung publik di mana di dalamnya terdapat toilet. Selanjutnya dijelaskan juga dalam kamus tersebut mengenai pengertian toilet yaitu merupakan 'perangkat' di mana orang mengeluarkan limbah, perangkat berbentuk mangkuk dengan kursi yang memiliki lubang di dalamnya (https://dictionary.cambridge.org/us/ dictionary/english/restroom).Restroom memiliki pengertian yang lebih tepat untuk menunjukkan sebuah ruang yang difungsikan tidak hanya untuk keperluan buang air besar (BAB) atau buang air kecil (BAK) tetapi di dalamnya juga ada fasilitas untuk cuci tangan maupun cuci muka. Dengan demikian di dalam restroom disediakan perangkat berupa toilet atau disebut juga dengan closet, urinoir, bidet, washtafel, dan Iain-lain. Di Indonesia ada pergeseran makna 'toilet' sehingga sering terjadi walaupun tidak semuanya bahwa tempat-tempat umum untuk menyebut ruangan yang fungsinya untuk kebutuhan tersebut dinamakan dengan toilet.

Fasilitas penunjang berupa restroom pada bangunan umum di Surakarta sebagai kota budaya, bisnis dan perdagangan sudah semestinya memiliki standar yang baik karena hal ini terkait dengan sanitasi, kebersihan dan kenyamanan bagi pengguna yaitu masyarakat umum. Disamping itu restroom juga bisa menjadi sarana menampilkan keunikan budaya lokal Surakarta dilihat dari bentuk desainnya.
Restroom dari sisi fungsi harus memperhatikan beberapa persyaratan yang baik mengenai dimensi atau ukuran ruang, sirkulasi udara terkait dengan kelembaban, sistem pencahayaan, dan konstruksi bangunan baik mengenai lantai, dinding dan langit-langit.

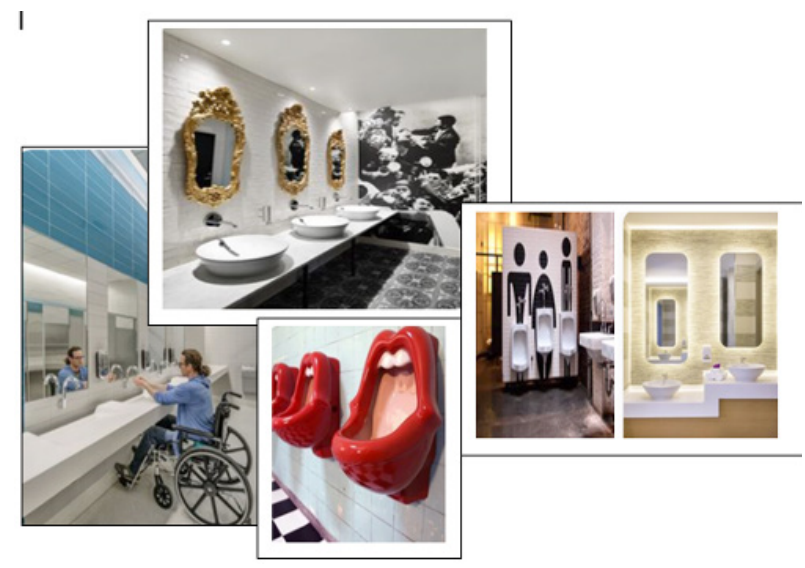

Gambar 1. Contoh restroom dan perangkat di dalamnya dengan bentuk sesuai karakter masing-masing budaya dan fungsi yang lebih optimal karena memperhatikan desain universal. (Sumber: https://id.pinterest.com/hpproducts/public-restroom-design-inspiration/, diakses tanggal 24/04/2020).

Bentuk restroom bisa didesain inovatif dengan membawa karakter lokal yang dimiliki budaya kota Surakarta. Gubahan bentuk ruang restroom dengan tema lokal dapat diaplikasikan pada unsur pembentuk ruang meliputi lantai, dinding dan ceiling. Hal serupa juga bisa diterapkan pada unsur pengisi ruang seperti perangkat toilet meliputi closet, bidet, orinoir maupun washtafel dan asesories ruang yang ditambahkan dalam ruang restroom. Surakarta memiliki banyak ragam hias tradisional 'iconic' yang biasa diaplikasikan pada berbagai seni nusantara seperti batik, lukis, atau seni kriya. Kearifan lokal tersebut sangat potensial dapat dimanfaatkan dalam perancangan restroom yang memiliki standar sanitasi dan kenyamanan yang baik sekaligus unik dan berkarakter Surakarta. Seluruh out put penelitian ini diahrapkan akan dapat bermanfaat bagi lembaga untuk pengayaan ilmu berupa bahan pembelajaran mata kuliah Desain Interior Hospitality yang terdapat pada kurikulum Program Studi Desain Interior ISI Surakarta. 


\section{B. Rumusan Masalah}

Permasalahan yang dapat dirumuskan dalam penelitian ini berdasarkan latarbelakang yang telah disampaikan di atas adalah sebagai berikut:

1. Bagaimanakah fungsi dan bentuk desain restroom pada bangunan publik di Surakarta?

2. Bagaimanakah mewujudkan optimalisasi desain restroom pada bangunan publik di Surakarta yang baik dan nyaman serta memiliki karakter budaya Surakarta?

\section{Tujuan}

1. Mengetahui fungsi dan bentuk desain restroom pada bangunan publik di Surakarta?

2. Mewujudkan optimalisasi desain restroom pada bangunan publik di Surakarta yang baik dan nyaman serta memiliki karakter budaya Surakarta?

\section{Metode Penelitian}

Metodologi penelitian terapan dengan judul "Optimalisasi Desain Restroom Pada Bangunan Publik di Surakarta" ini akan membatasi wilayah obyek material dengan studi kasus terhadap fasilitas restroom pada bangunan pusat perbelanjaan moderen (mall) yang terdapat di kota Surakarta. Metode penelitian ini terdiri dari beberapa bagian yang saling menunjang. Bagian-bagian tersebut dapat dijelaskan sebagai berikut :

\section{Tempat dan Waktu Penelitian}

Lokasi penelitian di kota Surakarta, merupakan kota yang sedang berkembang menuju kota budaya, bisnis, dan perdagangan. Pembangunan infrasturktur kota berupa gedung-gedung publik membutuhkan fasilitas penunjang berupa restroom yang memadahi baik dari segi fungsi dan bentuk desainnya.

Penelitian dilakukan selama 6 bulan dengan rincian sebagai berikut: (1) Persiapan Penelitian, (2) Penulisan Proposal, (3) Studi Pustaka, (4) Observasi, (5) Pengum- pulan Data, (6) Analisa Data, (7) Desain dan Eksperimentasi (8) Penyusunan Laporan, (8) Penggandaan dan Penjilidan Laporan.

\section{Pendekatan dan Strategi Penelitian}

Bentuk penelitian diskriptif kwalitatif dengan pendekatan desain dan estetis yang mengarah kepada out put dalam bentuk desain dan prototype. Dalam penelitian akan mengumpulkan banyak data terkait dengan ruang lingkup restroom dan implementasinya untuk perancangan restroom pada bangunan publik agar supaya lebih optimal. Data literatur dan data lapangan yang diperoleh kemudian akan dianalisa untuk merumuskan alternatif desain sehingga akan mendapatkan desain restroom yang terpilih. Proses selanjutnya adalah uji-coba desain melalui eksperimentasi yang nantinya akan menghasilkan prototype yang siap untuk direkomendasikan kepada pihak-pihak yang berkepentingan.

\section{Sumber Data dan Teknik Pengumpulan Data}

Beberapa jenis sumber data yang diperlukan dalam penelitian ini antara lain :

1) Artefak berupa berbagai restroom pada bangunan pusat perbelanjaan moderen (mall) yang ada di Surakarta, untuk diidentifikasi dan dianalisa dalam rangka analisa data untuk pengembangan yang lebih baik.

2) Sumber pustaka yang terkait dengan restroom.

Teknik pengumpulan data dalam penelitian ini meliputi :

1. Observasi terhadap sumber data di lapangan terkait dengan kondisi restroom yang terdapat pada bangunan pusat perbelanjaan modern (mall) di Surakarta.

2. Mempelajari dan mengkaji kepustakaan yang dapat memberikan informasi mengenai restroom.

\section{Validitas Data}

Pemeriksaan keabsahan data dilakukan dengan teknik triangulasi sumber yang berarti membandingkan dan mengecek baik 
derajat kepercayaan suatu informasi yang diperoleh melalui waktu dan alat yang berbeda dalam metode kualitatif (Patton dalam Lexy J. Moleong, 1996: 178). Dalam penelitian ini dapat dicapai dengan membandingkan data hasil pengamatan terhadap desain restroom di lapangan dengan hasil wawancara terhadap berbagai sumber yang kompeten dalam bidang tersebut.

\section{Analisis Data}

Proses analisis data dimulai dengan menelaah seluruh data yang tersedia dari berbagai sumber yang berkaitan dengan desain interior, restroom, dan standar perancangan resrtroom. Setelah itu mengadakan reduksi data melalui abstraksi sebagai usaha membuat rangkuman yang inti, proses dan pernyataan-pernyataan yang perlu dijaga sehingga tetap berada di dalamnya. Kemudian menyusunnya dalam satuan-satuan. Satuan-satuan tersebut dikategorisasikan sambil membuat koding. Kemudian tahapan terakhir adalah mengadakan pemeriksaan keabsahan data. (Lexy J. Moleong, 1996: 190).

\section{Tahapan Penelitian}

Penelitian ini dalam prosesnya bisa dilihat pada diagram di bawah ini:

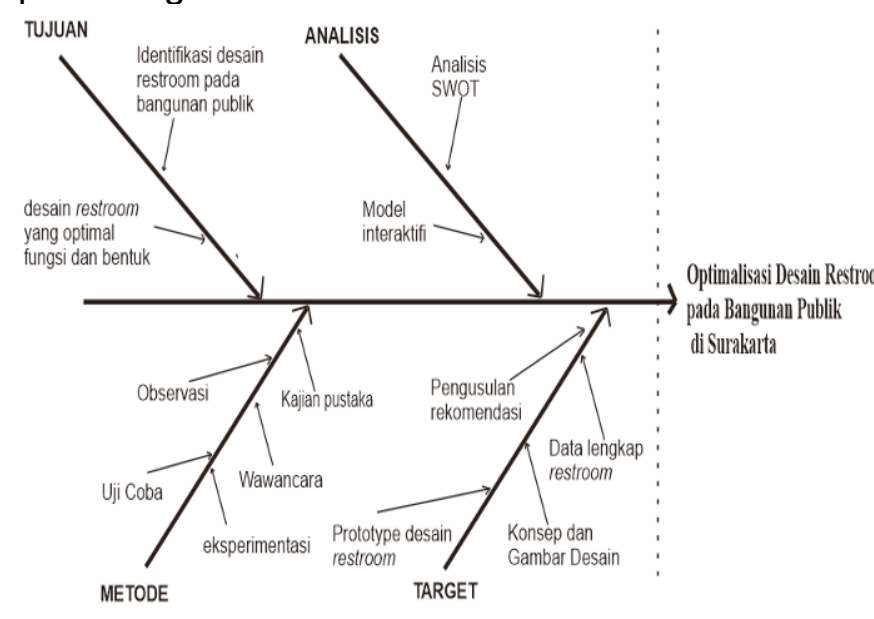

Gambar 2. Diagram Fishbone Rencana Penelitian Optimalisasi Desain Restroom Pada Bangunan Publik di Surakrata (Sumber: Agung, 2020)

\section{Luaran Penelitian}

Penelitian dengan judul "Optimalisasi Desain Restroom pada Bangunan Publik di Surakar- ta" ini memiliki target luaran berupa:

1. Naskah publikasi ilmiah

2. Presentasi hasil Penelitian Terapan

3. Model/Prototype/Desain

4. $\mathrm{HKI}$

\section{E. Kajian Pustaka}

Untuk memposisikan penelitian yang akan dilakukan terhadap penelitian terdahulu dengan bidang yang sama baik dari sisi metode, cara kerja, pendekatan yang digunakan maka dilakukan tinjauan pustaka.

1. Yusita Kusumarini \& Tri Noviyanto Puji Utomo, Konsep Desain Kamar Mandi Bertema "Accessible Restroom" 2007 Analisis Penerapan Konsep 'Desain Universal' pada Sayembara Perancangan, dimuat dalam Jurnal ITB J. Vis. Art \& Des. Vol. 2, No. 1, 2008, 85-98. Kamar mandi adalah ruang yang mengakomodasi ragam aktivitas yang cukup tinggi. Selain aspek estetik, fungsi, dan ekonomi, kriteria utama lain yang diharapkan adalah kemampuan desainer interior dalam mengkompromikan kebutuhan spesifik pengguna berkebutuhan khusus dengan kebutuhan kelompok lain yang dapat disebut normal. Fasilitas bangunan-ruang fisik dengan pendekatan universal (inklusif) sebagai konsekuensi bangunan-ruang publik tersebut, belum menjadi terapan yang umum di Indonesia. Desain bangunan-ruang fisik yang ada dan diterapkan saat ini banyak yang masih belum mempertimbangkan kebutuhan pihak-pihak yang memiliki keterbatasan fisik, rentang usia tertentu, dan juga perbedaan jenis kelamin secara imbang. Paradigma berpikir bahwa terapan desain universal atau inklusif adalah terapan yang mahal mengakibatkan belum ada upaya yang cukup untuk aplikasi dan pengembangan desain universal atau inklusif tersebut. Padahal dengan terapan desain universal, secara tidak langsung akan mempermudah semua pengguna fasilitas tanpa terkecuali. Dengan demikian produktivitas pengguna dapat ditingkatkan untuk menghasilkan buah investasi apabila suatu saat mengalami degradasi usia maupun fisik. 
2. Mahendra Nur Hadiansyah, Desain Urinoir, Dan Pria Studi Kasus, Toilet Umum Pria Paris Van Java (PVJ) Mall-Bandung, dimuat dalam Jurnal Desain Inerior, Vol 3, No 2 (2018). Area urinoir pada pria dianggap cukup berisiko terhadap penurunan tingkat privasi pengguna dari sisi visual sehingga berdampak pada psikologi pengguna yang menggunakan urinoir secara tidak maksimal. Penelitian ini bertujuan untuk mengidentifikasi kenyamanan pengguna dan masalah keamanan yang timbul berdasarkan dampak dari desain area urinoir dan penataan interior pada toilet pria. Metode penelitian melalui observasi yang disinergikan dengan data pengguna menggunakan studi kasus, yaitu toilet pria di mal Paris Van Java (PVJ) Bandung. Secara garis besar, hal-hal yang mempengaruhi tingkat kenyamanan dan keamanan pengguna urinal dalam privasi visual muncul dari desain bentuk produk urinoir yang digunakan, penggunaan penyekat antar urinoir, jarak antar urinoir, dan arah hadap urinoir terkait sirkulasi antar pengguna toilet yang mempengaruhi jangkauan visual.

3. Elisabeth Deta Lustiyati dan Merita Eka Rahmuniyati, Aksesibiitas Sarana Sanitasi Bagi Difabel di Tempat Tramsportasi Umum, dimuat dalam Jurnal of Disability Studies Inklusi. Para difabel sering mengalami hambatan karena tidak terdapatnya fasilitas yang aksesibel bagi mereka di tempat-tempat umum. Tujuan penelitian ini adalan untuk memperoleh gambaran aksesibilitas toilet umum bagi difabel di tempat transportasi umum DIY. Hasil dari penelitian ini menunjukkan bahwa aksesibilitas layanan sanitasi di bandara Adisucipto dan semua stasiun kereta api sudah baik; sementara aksesibilitas di terminal Giwangan masih kurang.

Hasil penelitian yang sudah dipaparkan di atas secara umum memiliki kesamaan obyek material dengan penelitian yang akan dilakukan penulis tetapi ada perbedaan dalam obyek formalnya. Kasus yang dilihat dalam lingkup restroom oleh peneliti belum dibahas oleh peneliti terdahulu yaitu bagaimana mengkaji persoalan restroom secara menyeluruh tidak parsial dan selanjutnya dilakukan optimalisasi melalui perancangan. Dengan latarbelakang obyek formal yang berbeda juga berpengaruh kepada metode yang diterapkan. Metode secara umum hampir sama tetapi ada perbedaan spesifik dalam penelitian yang akan dilakukan oleh penulis yaitu adanya tahapan desain melalui eksperimentasi dan uji coba desain agar hasil penelitian ini bisa diterapakan di lapangan penelitian.

Pustaka acuan primer dalam penelitian ini meliputi sumber yang berkaitan dengan bidang ilmu desain interior dan standar restroom atau toilet yang universal.

1. Pamuji Subtandar (1999), Desain Interior, Jakarta: Djambatan. Buku acuan primer ini dimaksudkan utuk memberikan masukan kepada para desainer dan arsitek yang ingin mendalami lebih jauh tentang kosep desain interior yang disesuaikan dengan gaya hidup manusia pada masa kini. Perkembangan ilmu pengtetahuan dan teknologi sudah sedemikian maju sehingga desain interior perlu untuk selalu menyesuaikan diri sehingga bisa diterima oleh masyarakat. Dijelaskan di dalamnya mengenai lingkungan alam bisa dibawa ke dalam ruangan berwujud taman karena manusia ingin merasakan keadaan yang alamiah ke dalam lingkungan buatan (Subtandar, 1999: 85).

2. Ir. Wibowo, dkk (ed), Standard Toilet Umum Indonesia "Kering itu Sehat" Jakarta, Kementerian Kebudayaan dan Kepariwisataan. Buku panduan ini bermanfaat bagi pengelola tempat-tempat umum di Indonesia, demi memberikan pelayanan publik yang baik. Di dalam buku ini secara garis besar membahas mengenai persyaratan ruang, standar hygienes sanitasi, ketentuan penutup dan cara pemeliharaan toilet.

3. ATI (Asosiasi Toilet Indonesia), Pedoman Standar Toilet Umum Indonesia. Buku ini bertujuan pengadaan, pengelolaan, dan pelayanan pada Toilet Umum agar dapat lebih baik, bersih dan nyaman. Dengan memperbaiki sarana toiletumum tersebut maka dengan sendirinya akan meningkatkan kualitas hidup, kenyamanan serta kesehatan pengguna toilet Umum khususnya bangsa Indonesia 


\section{HASIL DAN PEMBAHASAN}

\section{A. Fungsi dan bentuk desain restroom pada bangunan publik di Surakarta}

Peninjauan data literatur yang berkaitan dengan restroom dalam penelitian terapan ini sangat diperlukan agar mendapatkan dasar pijakan dalam membantu menyusun konsep dan mengimplementasikannya ke dalam bentuk rancangan restroom yang lebih optimal. Hal penting untuk diketahui mengenai restroom yaitu pengertiannya, sejarah perkembangan dan bentuk restroom, dan standar perancangan restroom. Disamping itu juga perlu disampaikan mengenai ruang lingkup bangunan umum dimana memerlukan fasilitas penunjang berupa restroom untuk memberikan kenyamanan bagi masyarakat umum di dalam memanfaatkan fasilitas tersebut.

Istilah yang berakitan dengan restroom cukup banyak, merujuk kepada suatu tempat atau ruangan penunjang pada suatu bangunan yang berfungsi untuk aktivitas mandi, mencuci tangan atau wajah hingga buang air kecil juga buag air besar. Istilah-istilah yang tidak asing dan sering didengar antara lain: kamar mandi, jamban, kakus, WC (Water Closed), dan toilet. Kamar mandi identik sebagai ruangan untuk keperluan yang disebutkan di atas untuk bangunan rumah tinggal.

Restroom agar dapat berfungsi dengan baik, maka di dalam perancangannya mengacu pada beberapa persyaratan sebagai berikut: 1) persyaratan ruang yaitu ruang untuk buang air besar (WC) : $L=80-90 \mathrm{~cm}, \mathrm{P}=150-160$ $\mathrm{cm}, \mathrm{T}=220-240 \mathrm{~cm}$ dan ruang untuk buang air kecil (Urinoir) : $L=70-80 \mathrm{~cm}, T=40-45$ $\mathrm{cm}$; 2) sirkulasi udara sebaiknya mempunyai kelembaban 40 - $50 \%$, dengan taraf pergantian udara yang baik yaitu mencapai angka 15 air-change per jam (dengan suhu normal toilet 20-27 derajat celcius); 3) pencahayaan, sistem pencahayaan dapat menggunakan pencahayaan alami dan pencahayaan buatan. Iluminasi standar 100 - 200 lux ; 4) konstruksi bangunan dengan standar kemiringan minimum lantai 1 $\%$ dari panjang atau lebar lantai, ubin keramik yang dipasang sebagai pelapis dinding, gysum tahan air atau bata dengan lapisan tahan air, langit-langit, terbuat dari lembaran yang cukup kaku dan rangka yang kuat sehingga memudahkan perawatan dan tidak kotor (http://pustaka. pu.go.id/resensi-buku/standar-toilet-umum-indonesia/1G82G).

Ruang spasial manusia dalam beraktivitas diperhitungkan dengan ukuran gerak, bisa saat duduk, jongkok, berdiri, berjalan, merentangkan tangan, dan lain-lain. Dengan demikian dimensi tubuh manusia saat melakukan aktivitas tertentu merupakan fator penting di dalam perancangan interior agar hasilnya dapat berfugsi sesuai dengan kebutuhan yang diinginkan. Demikian halhal ini juga berlaku dalam perancangan restroom, harus memperhatikan ukuran anatomi tubuh manusia untuk menjadi acuan terhadap luasan ruang dan properti atau peralatan penunjang yang ada di dalamnya.
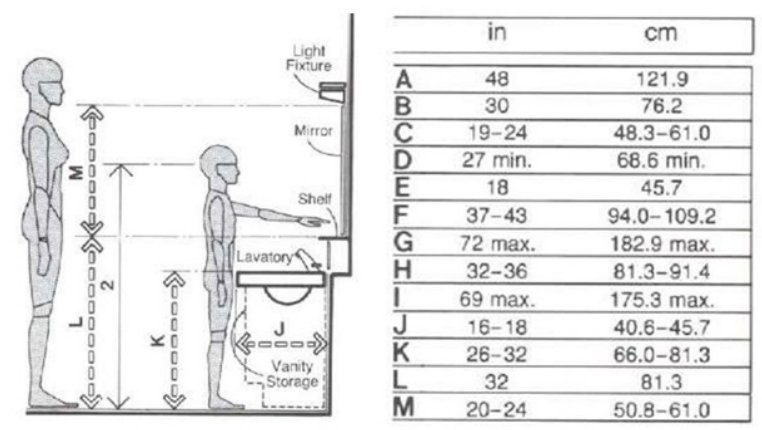

Gambar 3. Standar ukuran aktivitas manusia dan fasilitas penunjang pada wastafel area yang memperhatikan faktor usia.

(Sumber : Panero \& Zelnik, 1979)

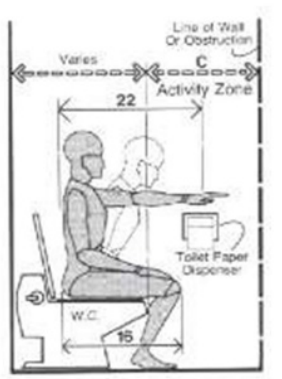

\begin{tabular}{|c|c|c|}
\hline & in & $\mathrm{cm}$ \\
\hline A & $12 \mathrm{~min}$. & $30.5 \mathrm{~min}$. \\
\hline B & $28 \mathrm{~min}$. & $71.1 \mathrm{~min}$. \\
\hline C & $24 \mathrm{~min}$. & $61.0 \mathrm{~min}$. \\
\hline D & $52 \mathrm{~min}$. & $132.1 \mathrm{~min}$. \\
\hline $\bar{E}$ & $12-18$ & $30.5-45.7$ \\
\hline $\mathbf{F}$ & 12 & 30.5 \\
\hline $\mathrm{G}$ & 40 & 101.6 \\
\hline$\underline{\mathrm{H}}$ & 18 & 45.7 \\
\hline 1 & 30 & 76.2 \\
\hline
\end{tabular}

Gambar 4. Standar ukuran aktivitas manusia dan fasilitas penunjang pada closet area.

(Sumber : Panero \& Zelnik, 1979)

Observasi lapangan dilakukan untuk memperoleh informasi mengenai kondisi exsisting restroom yang menjadi obyek penelitian. Data lapangan yang diperoleh kemudian dianalisa untuk mengetahui 
apakah beberapa restroom yang diteliti sudah memenuhi standar meliputi: 1) Interior system, desain restroom memperhatikan standar persyaratan ruang meliputi dimensi ruang, sirkulasi udara, pencahayaan, dan standar konstruksi bangunan; 2) Universalitas, berkaitan desain restroom yang dapat mengakomodir kebutuhan pengguna secara umum dengan memperhatikan kelompok usia dan bagi disabilitas; Local Content, desain restroom memiliki karakter budaya karena di dalamnya terdapat pengaplikasian unsur-unsur tradisi nusantara seperti bentuk ragam hias.

Data lapangan yang dihimpun diperoleh dari restroom sebagai fasilitas penunjang yang berada di beberapa pusat perbelanjaan moderen (mall) yang ada di Surakarta, diantaranya Solo Grand Mall, Solo Paragon Mall, Solo Hartono Mall, The Park Solo, dan Solo Square Mall.

1. Data Lapangan Restroom pada bangunan publik di Surakarta

Metode porposive sampling digunakan dalam penelitian ini untuk pemilihan obyek yang diamati. Pemilihan obyek penelitian tersebut mengarah kepada fasilitas penunjang berupa restroom pada bangunan pusat perbelanjaan moderen (mall) yang terdapat di wilayah kota Surakarta.

\section{a. Restroom pada Solo Grand Mall}

Solo Grand Mall mulai beroperasional sejak 4 Desember 2004 sebagai salahsatu mall terlengkap pada waktu itu. Pusat perbelanjaan yang beralamatkan di $\mathrm{Jl}$. Slamet Riyadi, Penumping, Laweyan, Kota Surakarta, Jawa Tengah ini menempati lahan seluas $12.080 \mathrm{~m}^{2}$ dan memiliki 7 lantai dengan luas keseluruhan bangunan 63.000 $\mathrm{m}^{2}$. Berbagai bidang usaha penjualan dan jasa tersedia dengan bergabungnya tenanttenant terkenal dengan produk fashion, kuliner, peralatan rumah tangga, stasionary hingga di bidang hiburan.

Bangunan Solo Grand Mall pada setiap tingkatan lantainya dilengkapi dengan fasilitas penunjang berupa restroom dengan tipikal yang sama. Pada restroom pria terdapat tiga pembagian area meliputi: 1 ) Wastafel area, di dalamnya terdapat 2 unit wastafel dan dilengkapi dengan fasilitas lain seperti cermin yang bergaya pop art, soap dispenser, wastebasket, dan air freshener; 2) Urinoir area, dilengkapi dengan 4 unit urinoir. Pada dinding untuk meletakkan urinoir terdapat perbedaan ketebalan lebih $15 \mathrm{~cm}$ dibanding dinding di atasnya sehingga permukaan datarnya bisa untuk menaruh barang bawaan; 3) Water closed area, terpasang 3 unit closet duduk di dalam setiap bilik.

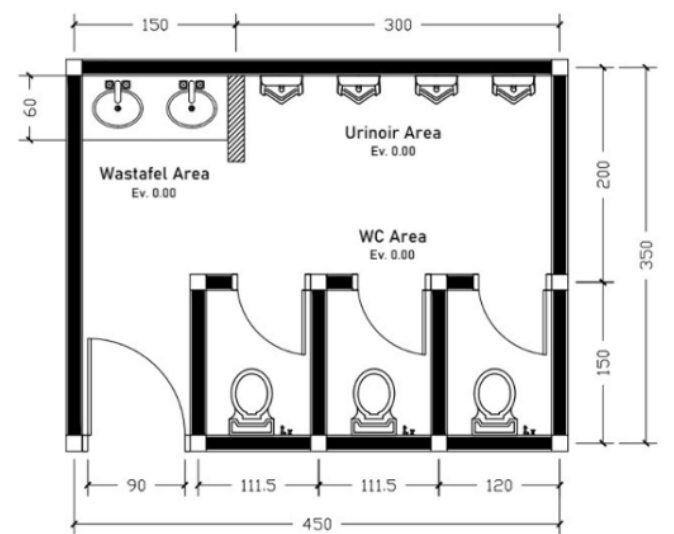

Gambar 5. Denah lay out restroom pada Solo Grand Mall. (Repto: Fitria, 2020)

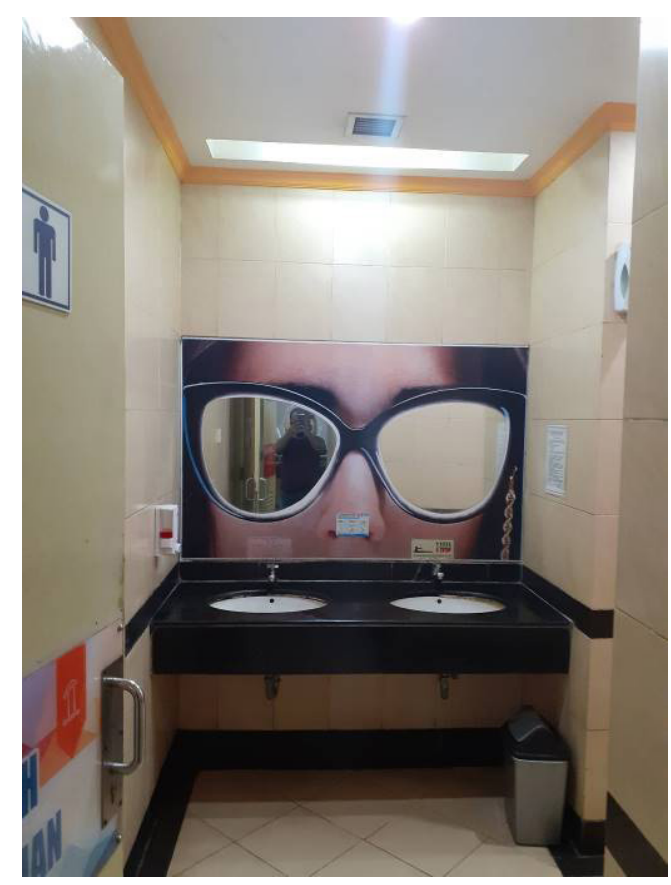

Gambar 6. Area Wastafel yang bergaya pop art dengan fasilitas pelengkapnya pada resrtroom di Solo Grand Mall. (Foto: Agung P, 2020) 


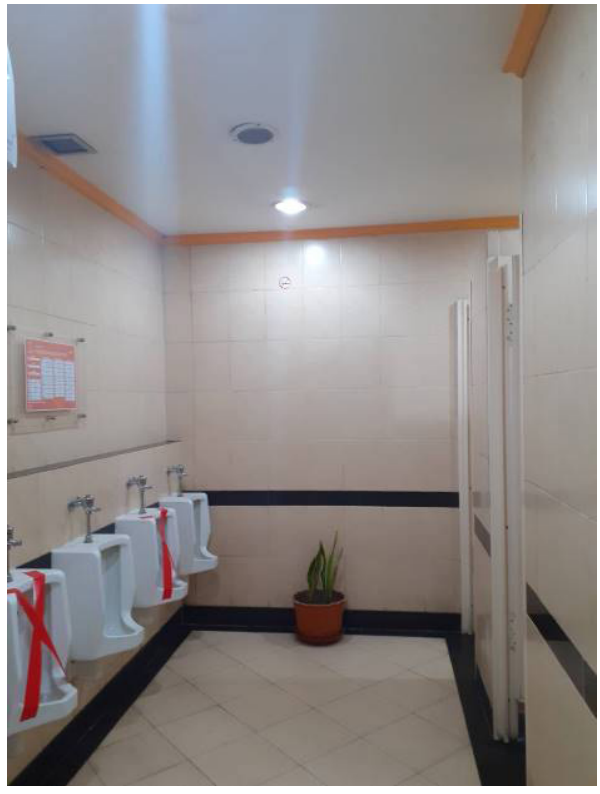

Gambar 7. Fasilitas urinoir berhadap-hadapan dengan water closed area di Solo Grand Mall. (Foto: Agung P, 2020)

\section{b. Restroom pada Solo Paragon Mall}

Solo Paragon Mall berlokasi di Jln. Yosodipuro no. 133, Solo. Dibuka untuk umum pada tahun 2011. Bangunan berlantai lima ini merupakan sebuah mall yang terdapat hotel dan residence sehingga sering disebut dengan Solo Paragon Lifestyle Mall, Hotel and Recidences. Gaya arsitekturnya moderen dengan sentuhan ragam hias tradisional Jawa yaitu hadirnya unsur unsur figur wayang baik pada eksterior maupun interiornya.

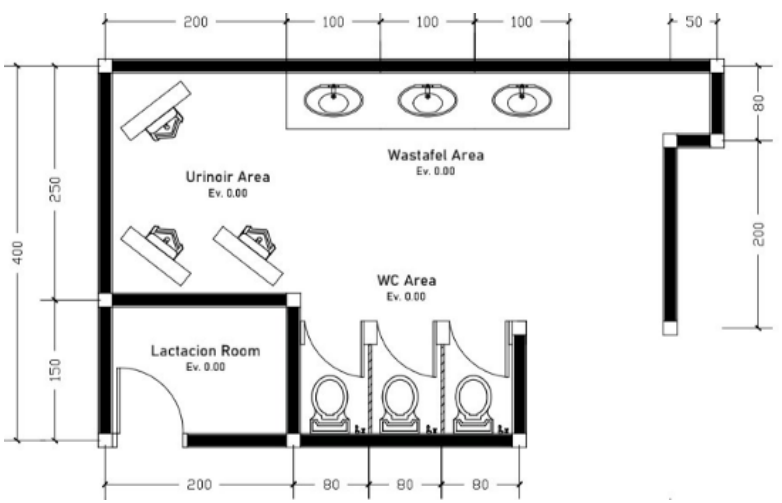

Gambar 8. Denah lay out restroom pria pada Solo Paragon Mall. (Repto: Fitria, 2020)

Tabel 1. Analisa kondisi restroom di Solo
Grand Mall

\begin{tabular}{|c|c|c|}
\hline Interior System & Universalitas & Local Content \\
\hline $\begin{array}{l}\text { Secara umum } \\
\text { m e m e n } \mathrm{h} i \\
\text { persyaratan, namun } \\
\text { ada beberapa } \\
\text { ke k u r ngan } \\
\text { mengenai dimensi } \\
\text { ruang pada akses } \\
\text { masuk yang } \\
\text { kurang nyaman } \\
\text { karena agak dekat } \\
\text { dengan wastafel } \\
\text { area, sehingga } \\
\text { mengganggu } \\
\text { sirkulasi }\end{array}$ & $\begin{array}{l}\text { Belum menyediakan } \\
\text { akses secara khusus } \\
\text { untuk memberikan } \\
\text { kemudahan bagi } \\
\text { pengguna dengan } \\
\text { usia anak-anak dan } \\
\text { bagi disabilitas. }\end{array}$ & $\begin{array}{l}\text { Tema } \\
\text { ruang yang } \\
\text { dihadirkan } \\
\text { bergaya pop } \\
\text { art, sama } \\
\text { sekali tidak } \\
\text { memasukkan } \\
\text { unsur-unsur } \\
\text { local. }\end{array}$ \\
\hline
\end{tabular}

Fasilitas penunjang berupa restroom pada setiap lantai memiliki tipikal tata susun area di dalamnya yang berbeda-beda namun tetap dengan nuansa yang sama yaitu memasukkan unsur figur wayang di pintu masuk restroom. Restroom pria pada lantai 1 di Solo Paragon Mall memiliki 3 area, meliputi: 1) wastafel area terdapat 3 unit wastafel dengan pembagian 2 unit wastafel untuk standar orang normal, sedangkan 1 unit wastafel yang posisinya agak rendah dan berada paling ujung diperuntukkan bagi para disabilitas. Fasilitas lain yang disediakan antar lain cermin, soap dispenser, wastebasket, tissue box, hand dryer, dan air freshener; 2) Urinoir area, terdapat 3 unit urinoir, dan ; 3) Closet area, terdapat 3 unit closet duduk dalam setiap bilik.

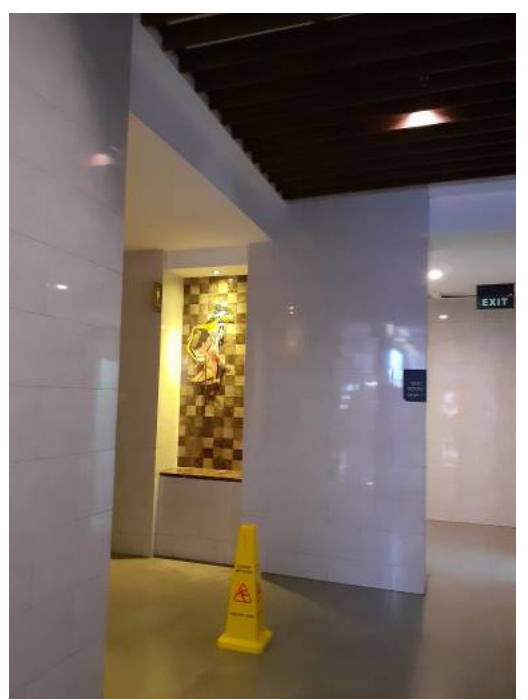

Gambar 9. Entrance yang memisahkan restroom untuk pria dan wanita di lantai 1 Solo Paragon Mall. (Foto: Agung P, 2020) 


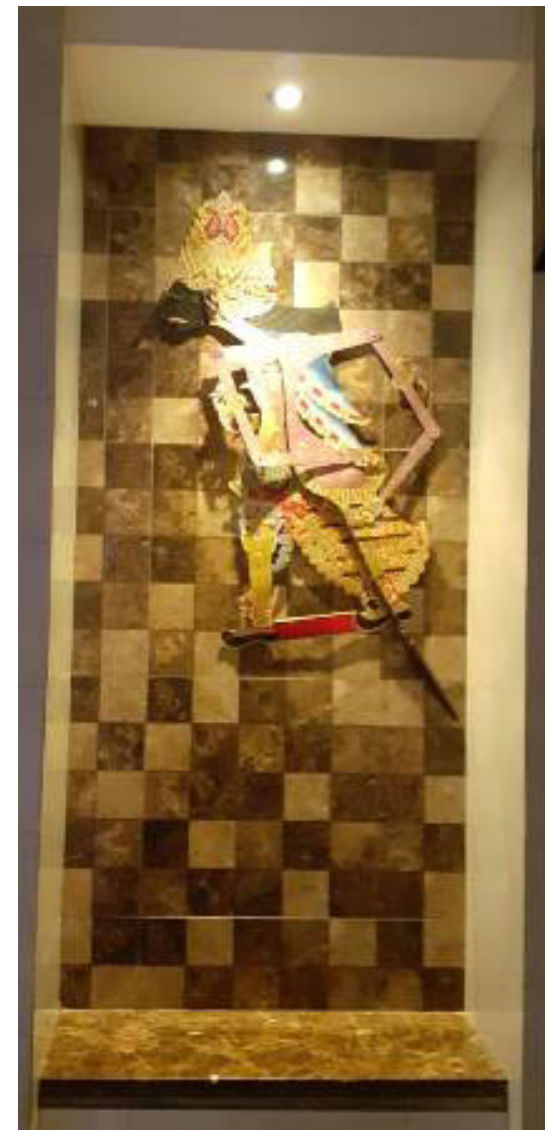

Gambar 10. Ragam hias berupa figur wayang yang ditampilkan pada Entrance untuk restroom pria di Solo Paragon Mall. (Foto: Agung, 2020)

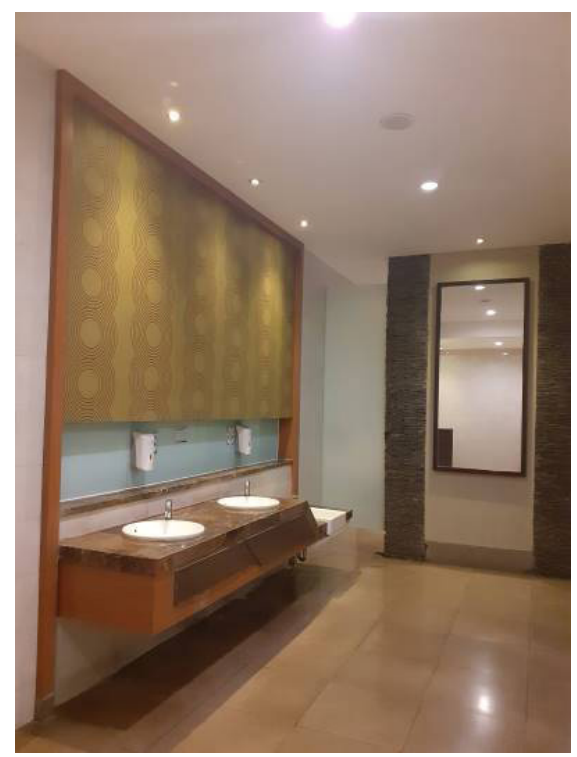

Gambar 11. Desain unit meja washtafel di restroom Solo Paragon Mall. (Foto: Agung, 2020)
Tabel 2. Analisa kondisi restroom di Solo Paragon Mall

\begin{tabular}{|c|c|c|}
\hline Interior System & Universalitas & Local Content \\
\hline $\begin{array}{l}\text { Secara umum } \\
\text { memenuhi } \\
\text { persyaratan meliputi } \\
\text { ukuran ruang, } \\
\text { sirkulasi udara, } \\
\text { pencahayaan, } \\
\text { dan konstruksi } \\
\text { bangunan. }\end{array}$ & $\begin{array}{l}\text { Sudah menyediakan } \\
\text { akses secara khusus } \\
\text { untuk memberikan } \\
\text { kemudahan bagi } \\
\text { pengguna dengan } \\
\text { usia anak-anak dan } \\
\text { bagi disabilitas. }\end{array}$ & $\begin{array}{l}\text { Menghadirkan } \\
\text { unsur karakter lokal } \\
\text { berupa figur wayang } \\
\text { kulit, namun hanya } \\
\text { bagian pintu masuk. } \\
\text { Bagian interior } \\
\text { restroom belum } \\
\text { diolah. }\end{array}$ \\
\hline
\end{tabular}

1. Restroom pada Solo Hartono Mall Lokasi Hartono Lifestyle Mall tberada di Jalan Ir. Soekarno, Solo Baru, Madegondo, Grogol, Sukoharjo. Pusat perbelanjaan ini pertama kali dibuka untuk umum pada tanggal 19 Oktober 2012 dengan menyajikan tenant sebanyak 150 unit yang diisi oleh penyewa-penyewa yang memiliki brand terkenal yang sudah tidak asing lagi bagi masyarakat.

Restroom untuk pria yang terdapat di Solo Hartono Mall dilengkapi faislitas pendukung yang terkelompok dalam tiga area yaitu; 1) Wastafel area, terdapat 3 unit wastafel. Fasilitas lain yang disediakan antar lain cermin, soap dispenser, wastebasket, tissue box, hand dryer, dan air freshener; 2) Urinoir area, tersedia 4 unit urinoir, dan ; 3) Closet area, terdapat 4 unit closet duduk dalam setiap bilik. Penerangan Restroom menggunakan pencahayaan umum dan pencahayaan khusus pada wastafel area, urinoir area, dan closet area. Tata kondisi ruang untuk penghawaan menggunakan penghawaan buatan berupa AC central.

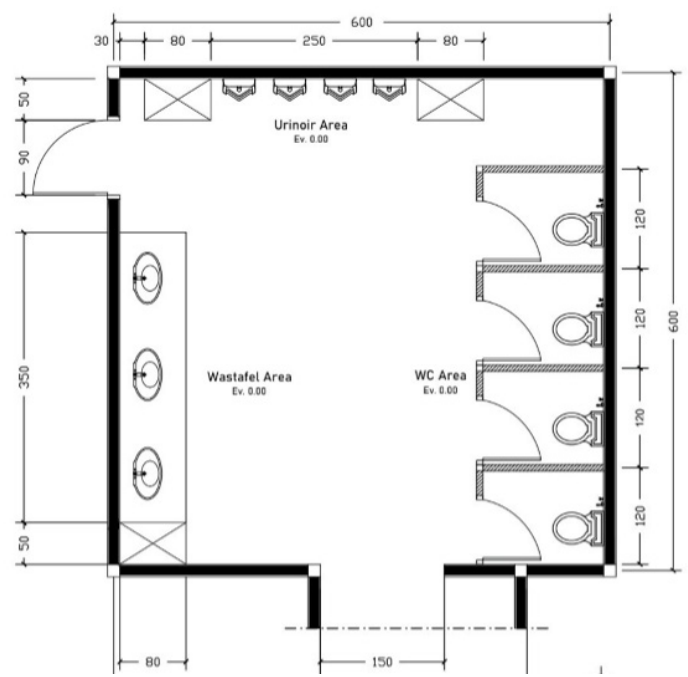


Gambar 12. Denah lay out restroom pada Solo Hartono Mall. (Repto: Fitria, 2020)

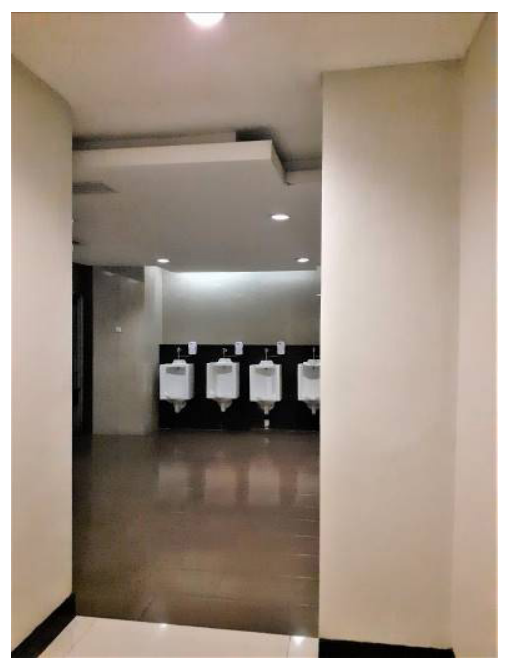

Gambar 13. Akses masuk ke dalam restroom di Solo Hartono Mall. (Foto: Agung P, 2020)

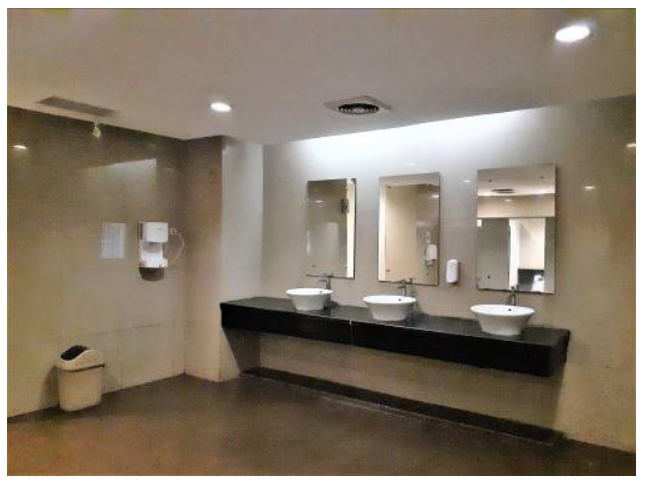

Gambar14. Wastafel area pada Solo Hartono Mall. (Foto: Agung P, 2020)

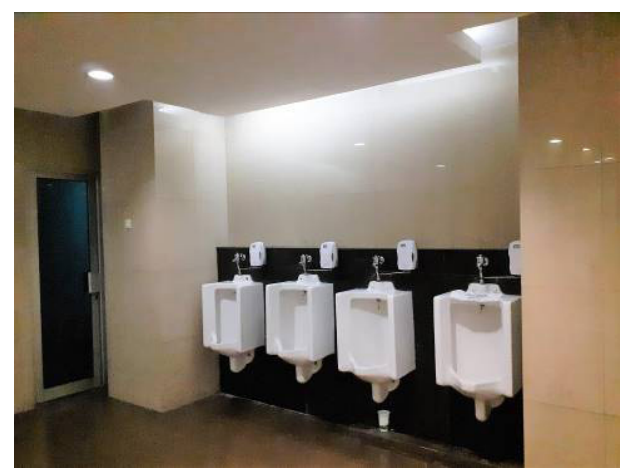

Gambar 15. Urinoir area pada Solo Hartono Mall yang dilengkapi dengan fasilitas pendukung berup 4 unit urinoir. (Foto: Agung P., 2020)

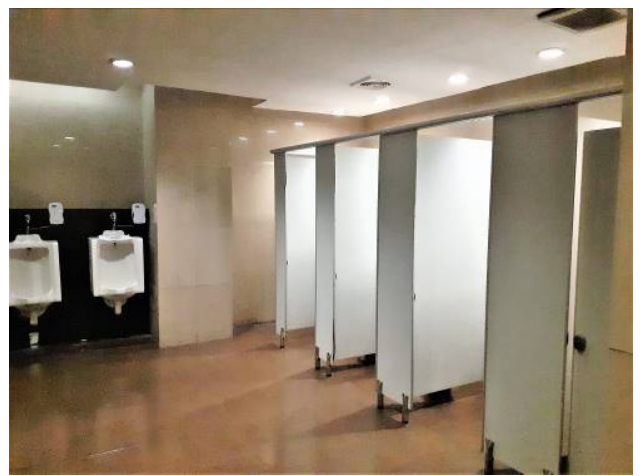

Gambar 16. Closet area yang dilengkapi dengan 4 unit closet duduk pada resstroom di Solo Hartono Mall. (Foto: Agung P., 2020)

Tabel 3. Analisa kondisi restroom di Solo Hartono Mall

\begin{tabular}{|l|l|l|}
\hline \multicolumn{1}{|c|}{ Interior System } & \multicolumn{1}{|c|}{ Universalitas } & Local Content \\
\hline Secara umum & Belum & Belum \\
memenuhi & menyediakan & menghadirkan \\
persyaratan & akses secara & unsur karakter \\
meliputi & khusus untuk & lokal di dalam \\
ukuran ruang, & memberikan & membentuk \\
sirkulasi udara, & kemudahan & atmosfir/tema \\
pencahayaan, & bagi pengguna & ruang. \\
dan konstruksi & dengan usia anak- & \\
bangunan. & anak dan bagi & \\
& disabilitas. & \\
\hline
\end{tabular}

2. Restroom di The Park Solo

The Park Solo berlokasi di JI. Ir. Soekarno, Solo Baru Madegondo, Grogol, Kbupaten Sukoharjo yang merupakan sebuah kawasan bisnis di kota bengawan. Pusat perbelanjaan ini memiliki luas bangunan lima hektar dengan mengusung konsep Lifestyle and Family Shopping Mall. The Park sebagai sebuah pusat perbelanjaan memiliki berbagai tenant antara lain Metro, XXI, Lottemart dan Ace Hardware.

Restroom yang terdapat pada The Park Solo memiliki gaya kontemporer dengan banyak mengolah bentuk lengkung pada elemen pembentuk ruang. Tata ruang di dalam restroom pria dibagi menjadi tiga area meliputi: 1) Watafel area, bentuknya menyerupai bak memanjang yang dilengkapi dengan 4 buah kran air. Pada area ini juga dilengkapi dengan fasilitas standar seperti cermin, soap dispenser, wastebasket, tissue box, hand dryer, dan air freshener . 2) Urinoir area, tersedia 5 unit urinoir, dan ; 3) Water Closet area, terdapat 3 unit closet duduk dalam setiap bilik. 


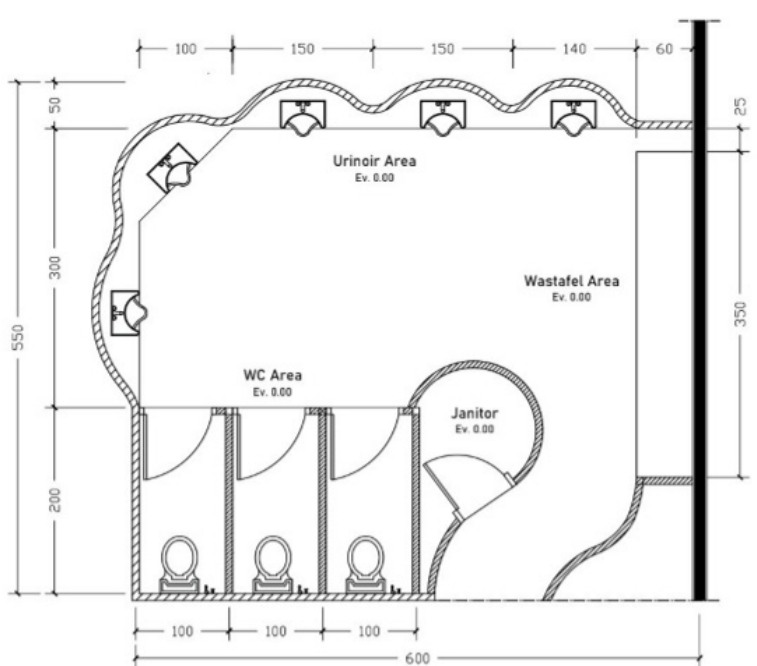

Gambar 17. Denah lay out restroom pada The Park Solo. (Repto: Fitria, 2020)

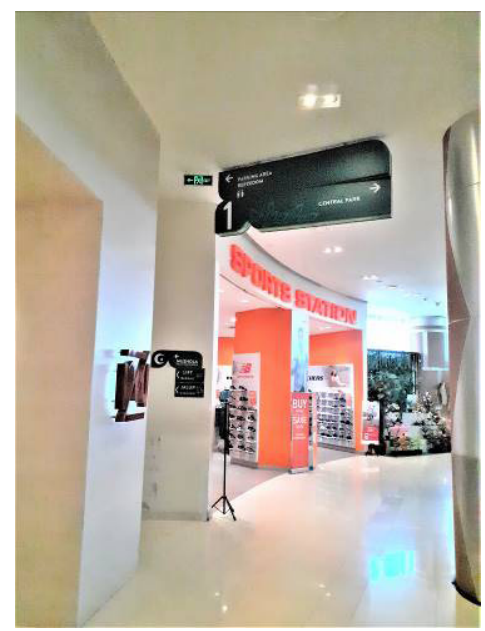

Gambar 18. Sign yang memberikan arah masuk menuju restroom di The Park Solo. (Foto: Agung P., 2020)

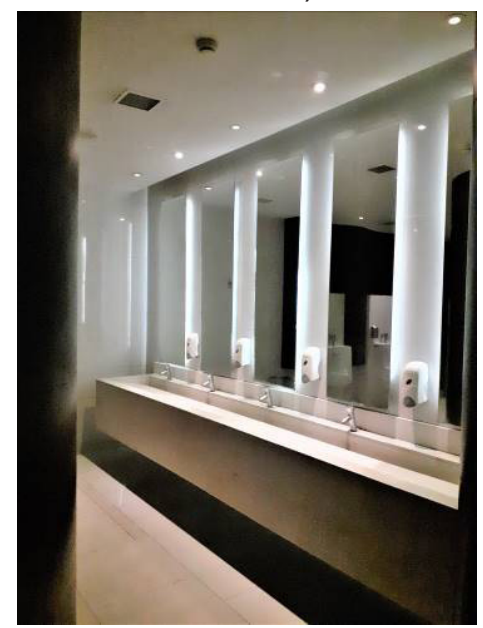

Gambar19. Wastafel area pada The Park Solo berbentuk bak memanjang yang dilengkapi dengan 4 buah kran air. (Foto: Agung P., 2020)

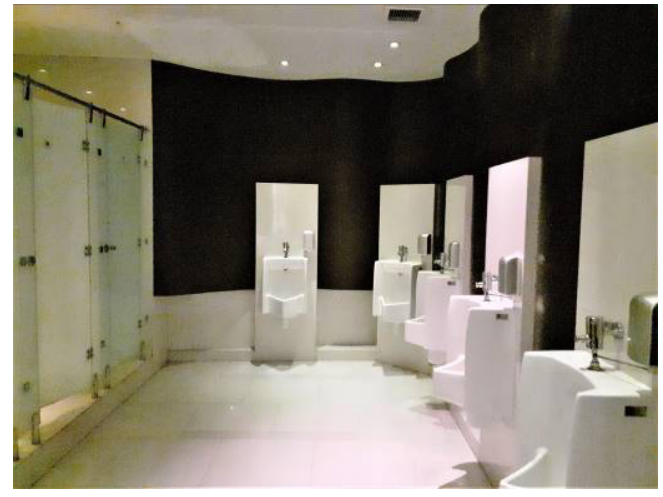

Gambar 20. Urinoir area yang bersebelahan dengan Water Closet area pada restroom di The Park Solo. (Foto: Agung P., 2020)

Tabel 4. Analisa kondisi restroom di The Park Solo

\begin{tabular}{|c|c|c|}
\hline Interior System & Universalitas & Local Content \\
\hline $\begin{array}{l}\text { Secara umum } \\
\text { memenuhi } \\
\text { persyaratan meliputi } \\
\text { ukuran ruang, } \\
\text { sirkulasi udara, } \\
\text { pencahayaaan, } \\
\text { dan konstruksi } \\
\text { bangunan. }\end{array}$ & $\begin{array}{l}\text { Belum } \\
\text { menyediakan } \\
\text { akses secara } \\
\text { khusus untuk } \\
\text { memberikan } \\
\text { kemudahan bagi } \\
\text { pengguna dengan } \\
\text { usia anak-anak dan } \\
\text { bagi disabilitas. }\end{array}$ & $\begin{array}{l}\text { Belum } \\
\text { menghadirkan } \\
\text { unsur karakter } \\
\text { lokal di dalam } \\
\text { membentuk } \\
\text { atmosfir/tema } \\
\text { ruang. }\end{array}$ \\
\hline
\end{tabular}

3. Restroom Solo Square Mall Lokasi Solo Square Mall berada di JI. Brigjend Slamet Riyadi No 451-455, Pajang, Laweyan, Surakarta. Seperti pusat perbelanjaan yang lain di kota Solo, mall berlantai lima ini juga menyajikan berbagai tenan dari perusahan-perusahan terkenal baik berskala nasional maupun internasional. Solo Square Mall di samping sebagai pusat perbelanjaan juga menyediakan wahana hiburan seperti cinema dan area bermain untuk anakanak.

Fasilitas penunjang berupa restroom tersedia di setiap lantai bagunan dengan tipikal yang sama. Restroom Solo Square Mall terbagi menjadi 3 area meliputi: 1) Wastafel area, terdapat 4 unit wastafel. Fasilitas lain yang disediakan antar lain cermin, soap dispenser, wastebasket, tissue box, hand dryer, dan air freshener; 2) Urinoir area, disediakan 8 unit urinoir, dan ; 3) Closet area, terdapat 2 unit closet duduk dalam setiap bilik. 


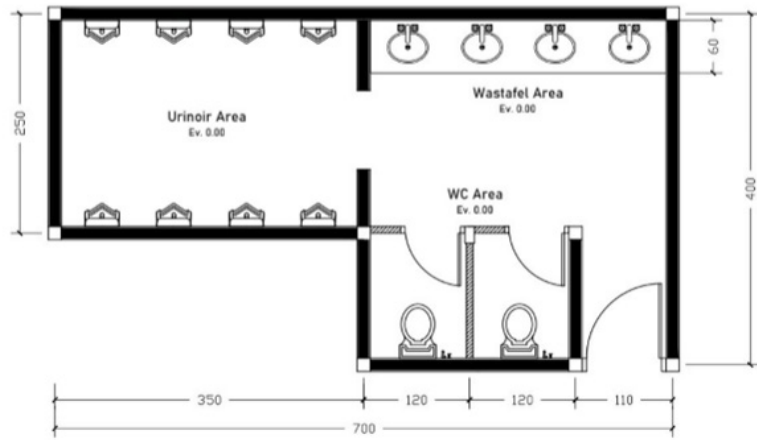

Gambar 21. Denah lay out restroom pada Solo Square Mall (Repto: Fitria, 2020)

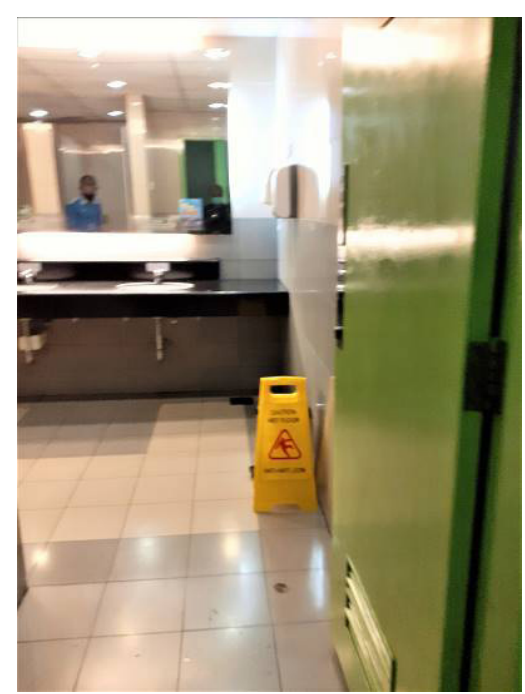

Gambar 22. Pintu masuk restroom pada Solo Square Mall. (Foto: Agung P, 2020)

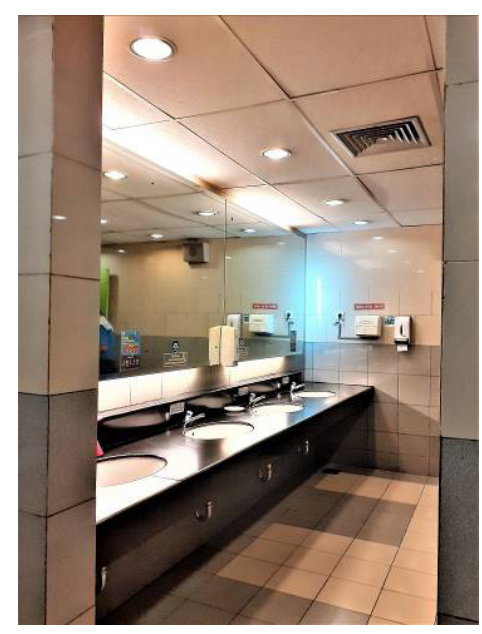

Gambar 23. Wastafel area pada restroom Solo Square Mall. (Foto: Agung P., 2020)

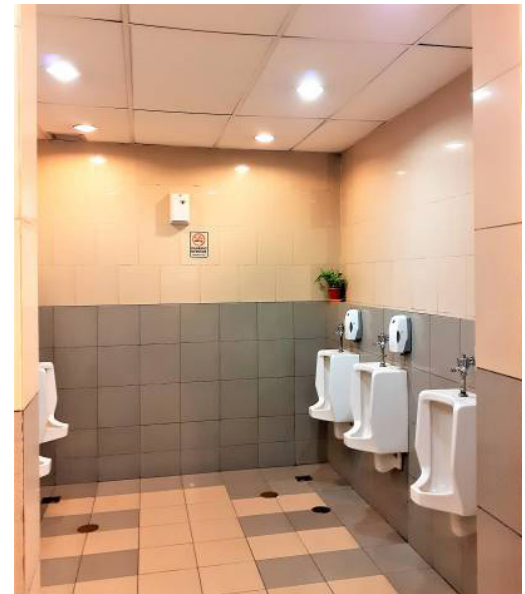

Gambar 24. Urinoir area pada restroom Solo Square Mall. (Foto: Agung P., 2020)

Tabel 5. Analisa kondisi restroom di Solo Square Mall.

\begin{tabular}{|c|c|c|}
\hline Interior System & Universalitas & $\begin{array}{c}\text { Local } \\
\text { Content }\end{array}$ \\
\hline $\begin{array}{l}\text { Secara umum } \\
\text { memenuhi } \\
\text { persyaratan } \\
\text { meliputi } \\
\text { ukuran ruang, } \\
\text { sirkulasi udara, } \\
\text { pencahayaan, } \\
\text { dan konstruksi } \\
\text { bangunan. }\end{array}$ & $\begin{array}{l}\text { Belum menyediakan } \\
\text { akses secara khusus } \\
\text { untuk memberikan } \\
\text { kemudahan bagi } \\
\text { pengguna dengan } \\
\text { usia anak-anak dan } \\
\text { bagi disabilitas. }\end{array}$ & $\begin{array}{l}\text { Belum } \\
\text { terdapat } \\
\text { unsur } \\
\text { karakter } \\
\text { lokal yang } \\
\text { diterapkan } \\
\text { dalam interior } \\
\text { restroom. }\end{array}$ \\
\hline
\end{tabular}

Data lapangan yang telah tersaji mengenai kondisi existing setiap restroom dari pusat perbelanjaan di Surakarta kemudian akan ditabulasi. Tujuan dari tabulasi data ini untuk mempermudah melihat kecenderungan kondisi masing-masing terkait interior sistem, universalitas, dan local content apakah menunjukkan kecenderungan dengan kondisi kurang, cukup, ataukah sudah baik.

Tabel 6. Tabulasi analisa data

\begin{tabular}{|l|l|l|l|l|l|l|l|l|l|}
\hline \multirow{2}{*}{ Nama } & \multicolumn{3}{|l|}{$\begin{array}{l}\text { Interior } \\
\text { System }\end{array}$} & \multicolumn{3}{|l|}{$\begin{array}{l}\text { Univer- } \\
\text { salitas }\end{array}$} & \multicolumn{3}{|l|}{$\begin{array}{l}\text { Local } \\
\text { Content }\end{array}$} \\
\cline { 2 - 9 } & $\mathrm{K}$ & $\mathrm{C}$ & $\mathrm{B}$ & $\mathrm{K}$ & $\mathrm{C}$ & $\mathrm{B}$ & $\mathrm{K}$ & $\mathrm{C}$ & $\mathrm{B}$ \\
\hline $\begin{array}{l}\text { Restroom Solo } \\
\text { Paragon Mall }\end{array}$ & & & $\mathrm{V}$ & & & $\mathrm{V}$ & & $\mathrm{V}$ & \\
\hline $\begin{array}{l}\text { Restroom Solo } \\
\text { Grand Mall }\end{array}$ & $\mathrm{V}$ & & $\mathrm{V}$ & & & $\mathrm{V}$ & & \\
\hline $\begin{array}{l}\text { Restroom Hartono } \\
\text { Mall Solo }\end{array}$ & & & $\mathrm{V}$ & $\mathrm{V}$ & & & $\mathrm{V}$ & & \\
\hline $\begin{array}{l}\text { Restroom Solo } \\
\text { Square Mall }\end{array}$ & & & $\mathrm{V}$ & $\mathrm{V}$ & & & $\mathrm{V}$ & & \\
\hline $\begin{array}{l}\text { Restroom The Park } \\
\text { Mall Solo }\end{array}$ & & $\mathrm{V}$ & $\mathrm{V}$ & & & $\mathrm{V}$ & & \\
\hline
\end{tabular}




\begin{tabular}{|l|l|l|}
\hline \multicolumn{3}{|l|}{ Keterangan: } \\
\hline K & $:$ & Kurang \\
\hline C & $:$ & Cukup \\
\hline B & $:$ & Baik \\
\hline
\end{tabular}

Tabulasi data memperihatkan bahwa rata-rata setiap restroom dalam aspek interior sistem seperti besaran ruang, sirkulasi udara, pencahayaan ruangan dan konstruksi bangunan sudah memenuhi standar yang baik. Pada aspek universalitas dimana restroom harus dapat mengakomodasi kebutuhan pengguna tanpa mengesampingkan faktor usia maupun bagi disabilitas masih kurang, hanya restroom di Solo Grand Mall yang sudah mencoba memfasilitasi kebutuhan tersebut. Sedangkan berkaitan aspek local content dari 4 pusat perbelanjaan hanya Solo Grand Mall yang menerapkannya, hanya saja desainnya masih kurang optimal karena hanya terlihat pada pintu masuk restroom sehingga kurang dapat memberikan pesan, kesan dan edukasi kepada masyarakat akan keberagaman kekayaan budaya nusantra.

Mencermati hasil analisa dari tabulasi data yang sudah tersaji, membawa kepada sebuah gagasan bahwa optimalisasai restroom akan dilakukan pada aspek local content, lebih menguatkan unsur local dengan mengaplikasikan ragam hias atau beragam bentuk artefak yang banyak kita kenali dan temukan di lingkungan budaya nusantara. Sedangkan obyek desain yang akan dioptimalkan adalah restroom untuk pria yang terdapat di Solo Paragon Mall.

\section{B. Optimalisasi Desain Restroom}

Bangsa kita memiliki banyak pengetahuan budaya sebagai bentuk kearifan lokal (local wisdom) yang dapat dikembangkan dalam berbagai bidang ilmu untuk memajukan peradaban bangsa ini. Kekayaan yang kita miliki tersebut tersebar di seluruh pelosok tanah air dengan berbagai ragam peninggalan salah satunya dalam bentuk artefak berwujud lingga-yoni dan beberapa motif batik Surakarta seperti kawung, sidomukti dan truntum. Dalam penelitian terapan ini akan mencoba mengangkat artefak tersebut untuk memberikan kekuatan karakter budaya yang bersifat local terhadap sebuah restroom.

Konsep bentuk lingga-yoni dan motif batik Surakarta menarik untuk dihadirkan pada restroom karena memiliki keunikan bentuk dan makna filosofinya. Lingga-yoni merupakan sebuah simbol kesuburan yang pada masa lalu biasanya dibuat dan diletakkan untuk menandai suatu wilayah yang subur lingkungan alamnya. Di beberapa negara dengan latar belakang agama Hindu memiliki bentukbentuk lingga-yoni dengan karakter yang berbeda-beda tak terkecuali di Indonesia.

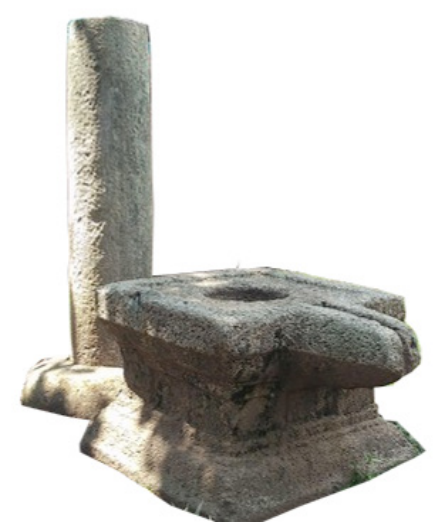

Gambar 25. Bentuk lingga-yoni yang terdapat di Kompleks Siti Inggil Keraton Kasepuhan Kota Cirebon, Jawa Barat. (Sumber: https://news.detik. com/berita-jawa-barat/d-3722804/artefak-lingga-dan-yoni-simbol-kejantanan-dan-kesuburan)

Batik Surakarta seperti kawung, truntum dan sidomukti sudah banyak dikenal oleh masyarakat luas di Indonesia bahkan mancanegara. Ada kebanggaan tersendiri bagi kita untuk tetap menjaganya agar tetap lestari dan dapat dikembangkan lebih luas ke bidangbidang yang lain termasuk desain interior. Motif batik tersebut memiliki bentuk yang menarik dengan kandungan filosofis yang tinggi. Motif kawung sudah pada awalnya digunakan oleh para keluarga bangsawan 
keraton, namun pada perkembangannya sudah masuk ke dunia fashion modern dan dapat dikenakan oleh segala lapisan masyarakat. Batik ini memiliki banyak makna antara lain mencerminkan hati yang bersih atau suci, sebagai lambang kebijaksanaan, pemersatu rakyat, dan diharapkan dapat bermanfaat bagi banyak orang.

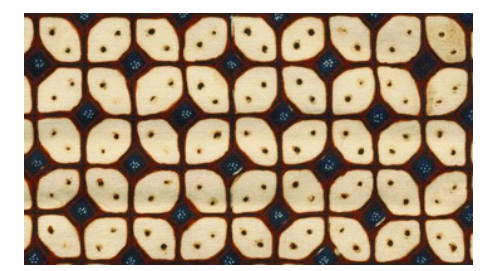

Gambar 26. Motif batik kawung (Sumber: https://batik-tulis.com/blog/batikkawung/)

Motif batik truntum secara visual memiliki beberapa analogi seperti tebaran bintang uang menghiasi langit malam. Truntum juga mengibaratkan bunga tanjung yang yang sedang tumbuh bersemi memiliki kuntum kemudian mekar kembali. Sehingga dibalik keindahan motif truntum tersebut tersirat makna sakral yaitu berseminya kembali cinta supaya abadi seperti mekarnya bunga pada motif tersebut yang tidak akan pernah layu.

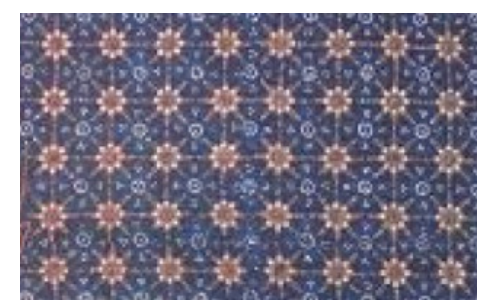

Gambar 27. Motif batik truntum

(Sumber: http://batik.or.id/filosofi-batik-motiftruntum/)

Motif batik sidomukti yang pada awalnya juga merupakan batik keraton memiliki makna harafiah sesuai dengan nama. Frasa sido mukti jika diurai artinya dari dua kata yaitu "sido" yang berarti "jadi", dan "mukti" yang berarti "sejahtera atau mulia". Dengan demikian motif batik sidomukti melambangkan suatu harapan hidup yang sejahatera agar dapat menjadi kenyataan.

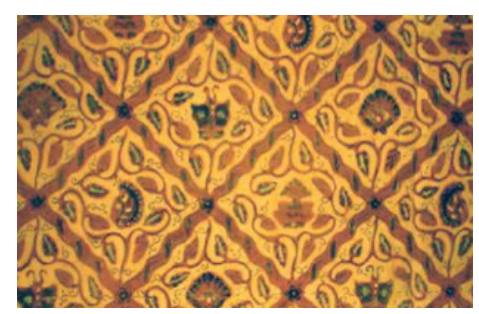

Gambar 28. Motif batik sidomukti (Sumber:https://batikdan.blogspot.com/2011/07/ batik-sidomukti-sidoluhur-sidomukti.html)

Rancangan desain dalam upaya optimalisasi restroom pada penelitian terapan ini akan mencoba mengambil sampel desain restroom lantai satu pada Mall Solo Paragon yang pada aspek visual masih kurang merepresentasikan tema dengan mengangkat unsur local content. Pada tahapan transformasi desain berupa lingga-yoni dalam perancangan restroom ini diarahkan ke fasilitas pendukung di wastafel area demikian juga untuk motif batik kawung, truntum, dan sido mukti.

a. Transformasi desain lingga-yoni

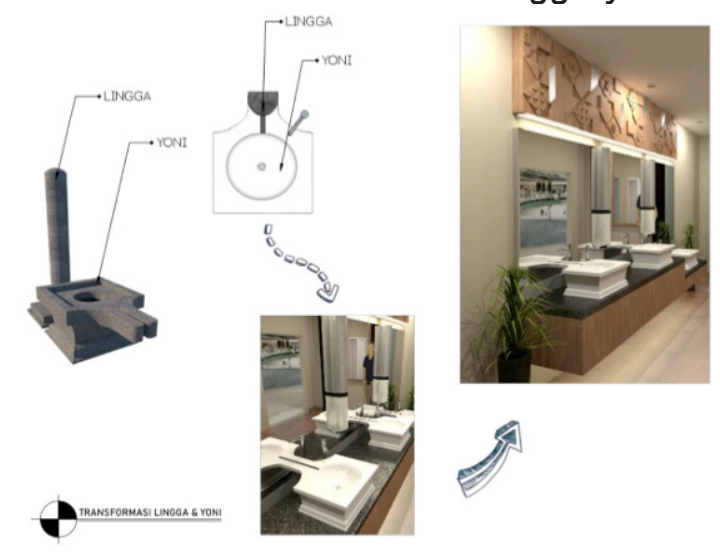

Gambar 29. Skema transformasi desain dari bentuk lingga-yoni menjadi desain wastafel. (Desain: Agung P, 2020)) 
Alternatif 1 desain wastafel
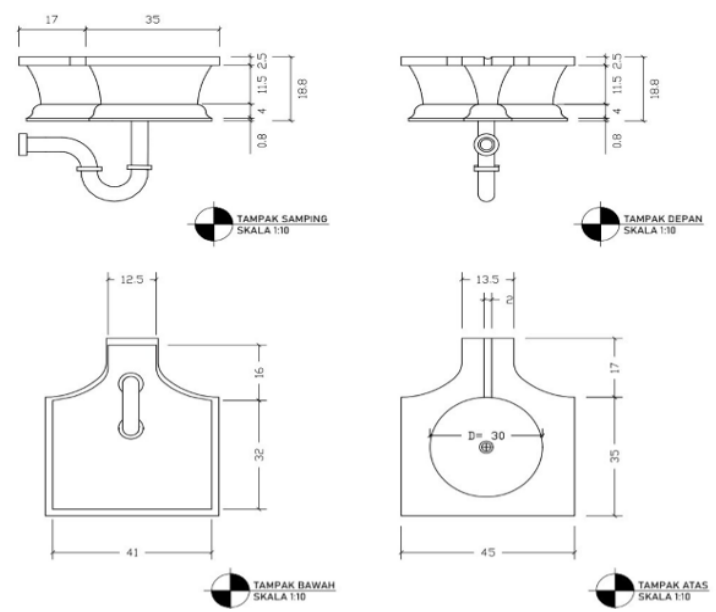

Gambar 30. Proyeksi desain wastafel alternatif 1. (Desain: Agung P., 2020))

\section{Alternatif 2 desain wastafel (Terpilih)}
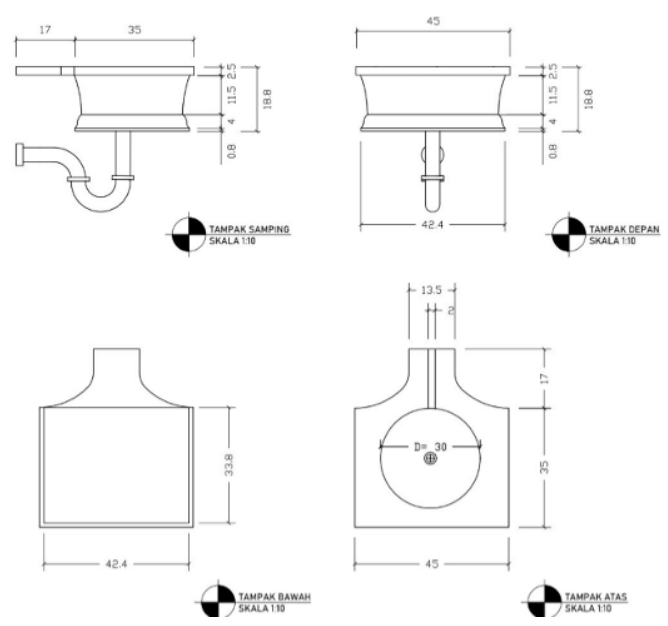

Gambar 31. Proyeksi desain wastafel alternatif 2.

(Desain: Agung P., 2020))

Gambar detail desain wastafel terpilih (Alternatif 2)

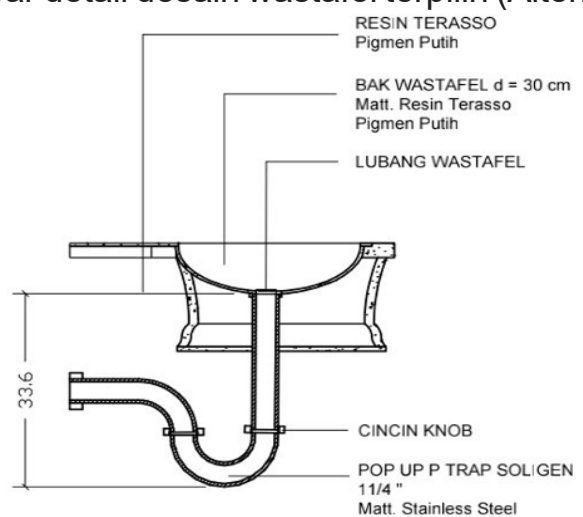

Gambar 32. Potongan desain wastafel yang terpilih (Alternatif 2) (Desain: Agung P., 2020)
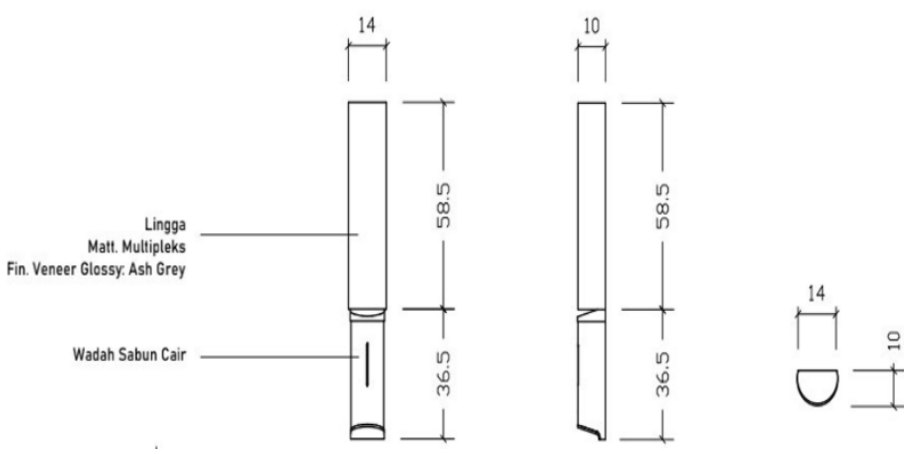

Gambar 33. Assesories pada cermin di wastafel area beberbentuk tabung yang terinspirasi dari lingga, juga berfungsi sebagai soap dispenser.

b. Transformasi desain motif batik kawung, truntum, dan sido mukti

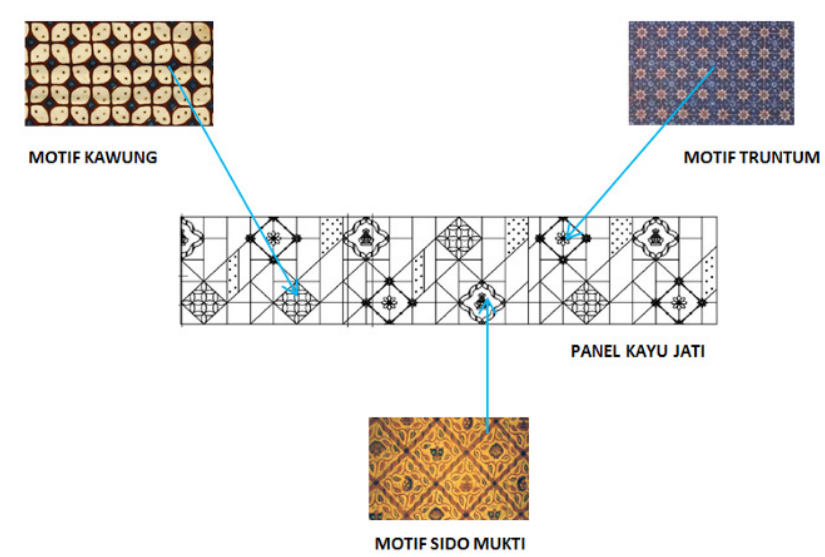

Gambar 34. Skema transformasi motif batik ke dalam bentuk desain panel untuk diaplikasikan di wastafel area. (Desain: Agung P., 2020)

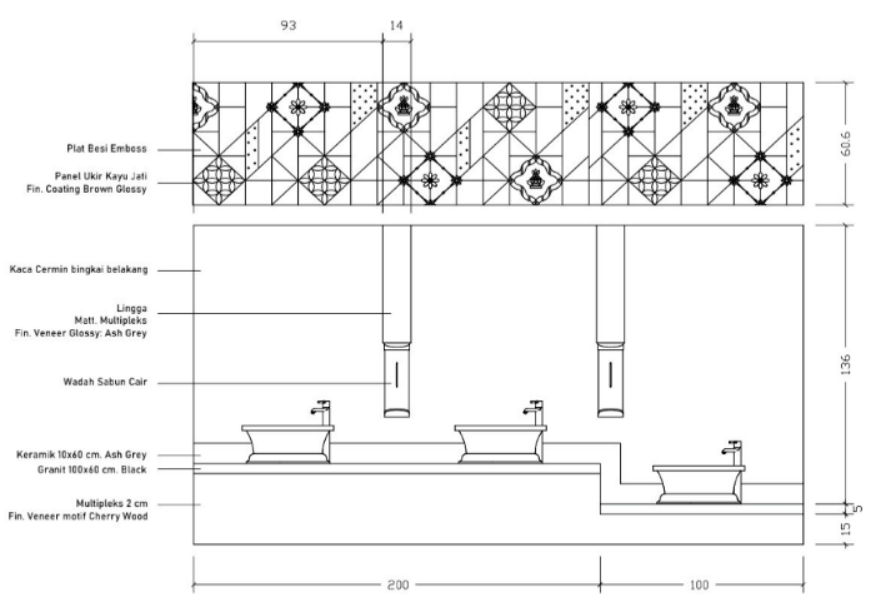

Gambar 35. Tampak depan dari gambar teknis restroom pada area wastafel. (Desain: Agung P., 2020) 


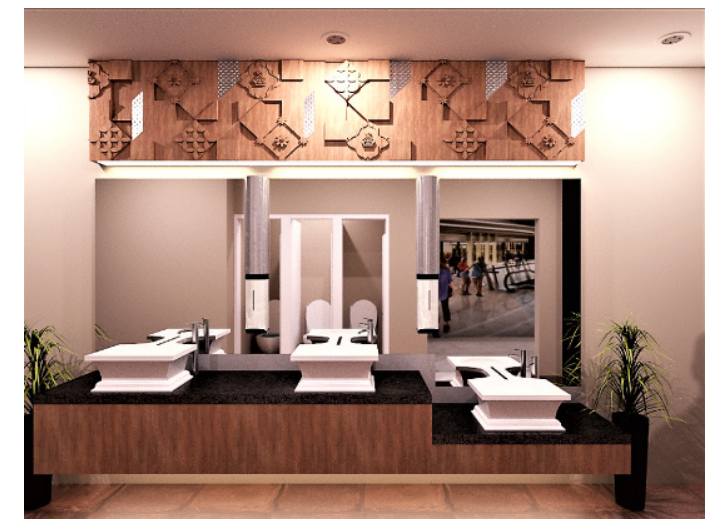

Gambar 36. Hasil dari optimalisasi desain interior restroom dalam bentuk gambar perspektif (view dari depan). (Desain: Agung P., 2020))

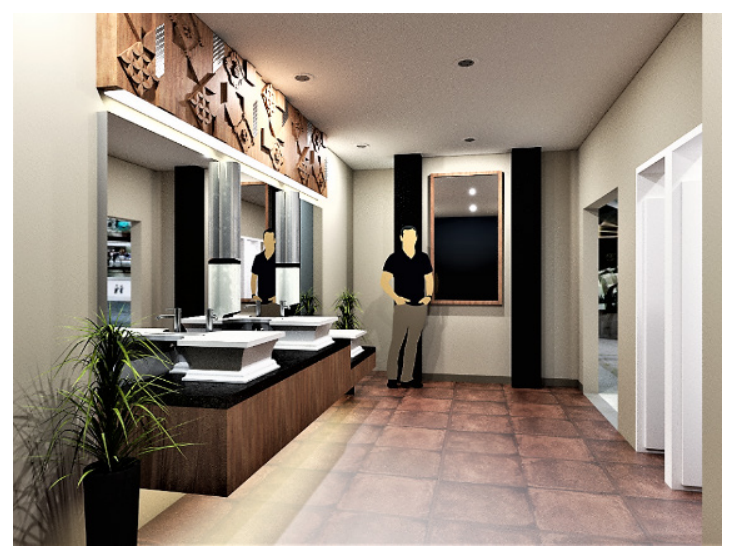

Gambar 37. Hasil dari optimalisasi desain interior restroom dalam bentuk gambar perspektif (view dari depan). (Desain: Agung P., 2020)

\section{KESIMPULAN}

Restroom sebagai fasilitas publik hendaknya dapat berfungsi secara optimal, di samping memenuhi standar pada aspek interior system dan memiliki kegunaan yang bersifat universal, sebaiknya juga terdapat nilai local content. Fasilitas restroom pada bangunan publik di Surakarta khususnya di pusat perbelanjaan (mall) pada umumnya secara iterior system seperti ukuran ruang, sirkulasi udara, pencahayaan, dan konstruksi bangunan.cukup memadahi. Pada aspek universalitas, di mana faslitas restroom dapat memberikan akses kepada segala segmentasi usia dan pemenuhan kebutuhan bagi disablitas belum begitu mendapatkan perhatian. Aspek local content yang dapat memberikan karakter terhadap bentuk dan suasana restroom masih sangat kurang, hanya beberapa saja yang sudah mewujudkannya.

Restroom pada bangunan publik di Surakarta dalam hal ini pusat perbelanjaan, kebanyakan belum memperhatikan pentingnya unsur local content untuk dimasukkan ke dalam desain interiornya. Lokal content budaya kita seperti ragam hias dan terfak yang lain dapat kita kembangkan ke dalam karya desain interior sehingga memiliki karakter. Di samping itu juga menjadi sarana edukasi bagi masyarakat sehingga akan lebih mengenal dan bangga akan kekayaan budaya yang kita miliki. Dalam penelitian terapan ini mencoba melakukan optimalisasi restroom pada aspek local content dengan memasukkan ragam hias berupa motif batik Surakarta untuk diterapkan pada dinding ruangan. Motif batik tersebut antara lain kawung, truntum, dan sidomukti. Unsur lokal yang lain adalah "lingga" dan "yoni", keduanya memiliki bentuk uniq dan menarik yang dapat ditransformasikan untuk fasilitas restroom berupa wastafel.

Hasil penelitian terapan ini diharapkan akan dapat bermanfaat kepada ilmu pengetahuan khususnya bidang ilmu desain interior dan bidang ilmu lain yang terkait. Tentunya masih terdapat aspek lain dalam penelitian ini yang bisa dikembangkan lebih lanjut melalui penelitian-penelitian yang berikutnya.

\section{DAFTAR PUSTAKA}

Herwibowo, Kunto, Budiana, N.S. (2015), Hidroponik Portabel, Penebar Swadaya, Jakarta.

https://dictionary.cambridge.org/us/dictionary/english/restroom, diakses pada 20/04/2020

http://pustaka.pu.go.id/resensi-buku/standar-toilet-umum-indonesia/1G82G, diakses pada tanggal 20/04/2020

Moeleong, Lexy J. . (1996). Metodologi Penelitian Kualitatif, Penerbit PT Remaja Rosdakarya, Bandung.

Pamudji, Suptandar, J. (1999). Desain Interior, Pengantar Merencana Interior untuk Mahasiswa Desain Interior, Djambatan, Jakarta. 
Satwikasari, Anggana Fitri (2013). Desain Taman sebagai Zona Terapi dan Edukasi Penyandang Cacat, Studi Kasus: Konsep Therapeutic Garden pada Redesain Bangunan YPAC Surakarta, dimuat dalam Prosiding Temu IImiah IPLBI.

Setyabudi (2016). Desain Taman Dengan Konsep Healing Garden Pada Area Napza di Rumah Sakit Jiwa (RSJ) Dr. Radjiman Wediodiningrat Lawang, dimuat dalam Jurnal Lanskap Indonesia, Volume 8 Nomor 2, 2016.

Soeseno, Slamet (1993). Taman Indah Halaman Rumah, Gramedia Utama, Jakarta.

Suharso (2000). Taman Mini,Kanisius, Yogyakarta 